\title{
Profanacja flagi państwowej a wolność slowa: sprawa Teksas vs. Johnson
}

Pierwsza poprawka do ustawy zasadniczej Stanów Zjednoczonych w sposób pozornie jednoznaczny zakazuje Kongresowi USA ustanawiania jakichkolwiek praw ograniczających wolność słowa ${ }^{1}$. Dostrzegalne prima facie prostota i ultymatywność wspomnianego przepisu są jednak dalece zwodnicze. Jak trafnie odnotowuje Eric Barendt, komentując pierwszą poprawkę, ,rzadko kiedy tak rzekomo klarowny tekst prawny stwarzał tak wiele problemów interpretacyjnych"2. Wyjaśnienie tego fenomenu jest relatywnie proste. Otóż analizowana tu klauzula konstytucyjna znajduje zastosowanie do tak wielu nader zróżnicowanych „obszarów konfliktu” wymagających przyjęcia specyficznych perspektyw analitycznych, doktrynalnych i orzeczniczych, że praktycznie niemożliwe jest sformułowanie na podstawie samego brzmienia pierwszej poprawki bezdyskusyjnych i niewatpliwych dyrektyw, pozwalających na ustalenie jej jednoznacznej wykładni, adekwatnej do mnogości relewantnych stanów faktycznych oraz prawnych. Wystarczy wskazać, że pierwsza poprawka - przynajmniej potencjalnie - dotyczy tak różnorakich zagadnień, jak chociażby manifestacje, polegające na okupowaniu miejsc czy budynków publicznych, używanie instrumentów nagłaśniających, organizacja rynku telewizji satelitarnej, kablowej czy naziemnej, reklamy w prasie drukowanej, stawianie billboardów, podżeganie do popełnienia przestępstwa, gloryfikowanie reżimów totalitarnych czy przemocy w życiu publicznym, publiczne

${ }^{1}$ Dodajmy, że na przełomie lat 20. i 30. XX w. federalny Sąd Najwyższy zaczął stosować przewidziane w pierwszej poprawce gwarancje do unormowań lokalnych i stanowych. Posunięcie to zostało uzasadnione tzw. doktryną inkorporacji, zgodnie z którą czternasta poprawka do konstytucji, zabraniająca stanom „,pozbawiania kogoś życia, wolności lub własności bez prawidłowego wymiaru sprawiedliwości", zawiera w sobie wyrażony implicite zakaz ograniczania praw jednostkowych wyeksplikowanych w Bill of Rights ( $\mathrm{tj}$. w pierwszych dziesięciu poprawkach do konstytucji federalnej). Zob. np. L. Garlicki, Bill of Rights w rozwoju konstytucji federalnej Stanów Zjednoczonych, w: Konstytucja USA 1787-1987. Historia i współczesność, red. J. Wróblewski, Warszawa 1987, s. 216-218.

2 E. Barendt, Freedom of speech, New York 2007, s. 48. 
posługiwanie się wulgaryzmami, ochrona praw autorskich, naruszanie cudzej prywatności, formułowanie wypowiedzi zniesławiających i znieważających, wyrządzanie komuś emocjonalnej krzywdy, granice wolności słowa na szczególnych forach (np. szkoła, Internet, armia), publikowanie materiałów o charakterze obscenicznym i wiele innych kwestii ${ }^{3}$. Suchy tekst pierwszej poprawki nie dostarcza nam zatem wystarczających instrumentów pozwalających na rozwiązanie skomplikowanych dylematów pojawiających się już choćby tylko w wymienionych powyżej okolicznościach. Jak lapidarnie konkluduje jeden z najwybitniejszych współczesnych konstytucjonalistów amerykańskich Geoffrey R. Stone, analiza słownikowa nie determinuje znaczenia konstytucyjnych klauzul ${ }^{4}$. Niemożliwe jest przeto traktowanie pierwszej poprawki w kategoriach absolutnych jako całkowitego zakazu regulowania przez państwo w jakikolwiek sposób jakiejkolwiek aktywności ekspresyjnej.

Powyższe stwierdzenie ma w gruncie rzeczy walor truizmu. Jak podkreśla Franklyn Saul Haiman, jeden ze znanych amerykańskich badaczy problematyki, znaczenie pierwszej poprawki przez cały okres jej egzystencji nigdy nie było uznawane za ,proste bądź absolutne. Ani Sąd Najwyższy, posiadający ostateczny głos w konstytucyjnych interpretacjach, ani wiodący uczeni, którzy studiowali i opisywali kwestię historii czy statusu swobody słowa w Ameryce, ani też największa i najgłośniejsza organizacja broniąca w USA obywatelskich wolności - Amerykańska Unia Wolności Obywatelskich - nigdy nie utrzymywali, że formuła o «żadnym prawie» zawarta w pierwszej poprawce powinna być rozumiana w sposób literalny i absolutny"'. Wydaje się, że klauzula wolności słowa powinna być w najogólniejszym sensie rozumiana jako gwarancja zapewniająca możliwie najszerszy i koherentny (tak pod względem aksjologicznym, jak i prakseologicznym) system ochrony swobody ekspresyjnej ${ }^{6}$. Poleganie wyłącznie na wykładni językowej okazuje się dla tak zarysowanego celu niewystarczające ${ }^{7}$. Konieczne staje się więc sformułowanie kompleksowej jurydycznej doktryny wolności słowa, która powinna prowadzić do ,zabronienia państwu dławienia wypowiedzi, które muszą być dopuszczalne w wolnej i demokratycznej społeczności oraz do zezwolenia państwu na karanie wypowiedzi powodujących szkody, którym państwo może w sposób uzasadniony zapobiegać. Osiagnięcie tego celu nie jest bynajmniej łatwym przedsięwzięciem. Istnieją oczywiście typy ekspresji, takie jak propozycje wprowadzenia, drogą pokojową i demokratyczną, określonych reform prawnych czy politycznych, które muszą być chronione przed państwową supresją.

${ }^{3}$ R.A. Smolla, Free speech in an open society, New York 1992, s. 18-19.

${ }^{4}$ G.R. Stone, Perilous times. Free speech in wartime: from the Sedition Act to the war on terrorism, New Yrok 2004, s. 6.

${ }^{5}$ F.S. Haiman, Speech and law in a free society, Chicago and London 1981, s. 3-4.

6 Por. T.I. Emerson, The system of freedom of expression, New York 1970, s. 15.

${ }^{7}$ Jak pisze Daniel A. Farber, ,the bare text of the First Amendment provides only a hint of the ultimate contours of legal protection", w: idem, The First Amendment, New York 1998, s. 1. 
I podobnie, nie można konstytucyjnie krępować państwa, uniemożliwiając mu kryminalizację takich wypowiedzi, jak składanie fałszywych żeznań, przekupstwo bądź też nakłanianie do popełnienia morderstwa. Ale co należy wobec tego uczynić z wypowiedziami propagującymi wprowadzenie społecznych zmian z użyciem przemocy lub za pomocą innych naruszających prawo zabiegów lub z wypowiedziami zniesławiającymi funkcjonariuszy publicznych? Albo z politycznymi protestami, posługującymi się obraźliwymi frazami w rodzaju «pieprzyć pobór do wojska» lub wykorzystującymi bulwersujący przekaz symboliczny w rodzaju palenia flagi państwowej? A co z dosadna ekspresją erotyczną, której głównym celem jest wzbudzenie u jej odbiorców podniecenia seksualnego?"8. Na gruncie amerykańskim zadanie wykreowania takiej doktryny z konieczności spoczęło na barkach federalnego Sądu Najwyższego.

Z punktu widzenia wzmiankowanej doktryny jednym z najbardziej kontrowersyjnych zagadnień jest kwestia aplikacji gwarancji przewidzianych w pierwszej poprawce do ekspresji niewerbalnej (lub zawierającej niewerbalne elementy). Czysto językowa interpretacja klauzuli wolności słowa uprawomocniałaby tezę, że omawiane postanowienie odnosi się jedynie do wypowiedzi werbalnych; o ile słowo - pisane lub mówione - podlegałoby ochronie pierwszej poprawki, o tyle zachowanie (czyli ,nie słowo") pozostawałoby całkowicie poza zakresem jej normowania. Tak radykalne założenie, pryncypialnie i rygorystycznie odmawiające ekspresji niewerbalnej jakiejkolwiek konstytucyjnej ochrony na mocy pierwszej poprawki, nie jest aprobowane przez ogromną większość komentatorów. Można powiedzieć, że w tym zakresie panuje wśród amerykańskich konstytucjonalistów pewien rudymentarny konsensus, zgodnie z którym niektóre zachowania niewerbalne sq - przynajmniej funkcjonalnym - ekwiwalentem słów oraz zasługuja tym samym na protekcję pierwszej poprawki ${ }^{9}$. Na poparcie takiej tezy wysuwane są trzy podstawowe argumenty. Pierwszy z nich ufundowany jest na sui generis fenomenologicznej analizie terminu ,słowo" oraz zjawiska komunikacji międzyludzkiej. Jak dowodzi Louis Henkin, dogmatyczne konstruowanie antynomii pomiędzy „słowem” i „nie słowem” jest pozbawione sensu: „Rozróżnianie pomiędzy słowem oraz działaniem jest fałszywe. Słowa to zachowania, a czyny przemawiają. Nie istnieje nic immanentnie świętego w machaniu językiem i w dzierżeniu pióra; nie ma nic immanentnie świętszego w słowach w porównaniu z innymi symbolami. Inne typy komunikowania się są także skuteczne

8 J. Weinstein, Hate speech, pornography, and the radical attack on free speech doctrine, „Boulder" 1999, s. 11.

${ }^{9}$ Spory dotyczą natomiast zasadności objęcia takimi gwarancjami konkretnych rodzajów ekspresji niewerbalnej. O ile niemal wszyscy współcześni komentatorzy byliby skłonni obejmować taką ochroną wywieszanie czerwonego sztandaru symbolizującego ideologię komunistyczna, o tyle istnieją wśród nich poważne rozbieżności dotyczące np. konstytucyjnego statusu palenia krucyfiksów przez organizacje rasistowskie. 
- [...] oddawanie honorów fladze, przyklęknięcie przy religijnej ceremonii, ujmowanie dłoni ukochanej osoby"10. Podobna diagnozę formułuje Melville B. Nimmer: „W pewnym sensie każde słowo jest symbolem. W tym momencie czytelnik obserwuje czarne znaczki na papierze, które wyginają się i wskazują w różnych kierunkach. Nazywamy owe znaki literami, a ich zgrupowania słowami. To, co zostaje wyrażone w tym zdaniu, posiada dane znaczenie wyłącznie dlatego, że czytelnik rozpoznaje przedmiotowe znaki jako symbole pewnych idei. Ta sama prawidłowość dotyczy słowa mówionego, które polega po prostu na wykorzystaniu symbolicznych dźwięków. Wyjąwszy obszar obecnej w świecie science fiction bezpośredniej komunikacji telepatycznej, każde porozumiewanie się wymaga posłużenia się symbolami" ${ }^{11}$. Rozpatrując wskazane tutaj zagadnienie $z$ nieco innej strony, można przyjąć, że skoro celem pierwszej poprawki jest zapewnienie możliwości istnienia - w określonych granicach - swobodnej, nieskrępowanej rządowymi regulacjami komunikacji międzyludzkiej, to ograniczenie zasięgu jej oddziaływania wyłącznie do wypowiedzi werbalnych jest z punktu widzenia powyższego telos ewidentnie przeciwskuteczne. Sytuacja komunikacyjna wymaga jednoczesnego wystapienia czterech elementów: nadawcy przekazu, odbiorcy przekazu, treści przekazu oraz zapośredniczającego medium pozwalającego nadawcy na przekazanie odbiorcy przedmiotowej treści. Medium tym mogą być nie tylko słowa, ale również gesty, sygnały, obrazy, czynności, takty muzyczne itp. Wszystkie wspomniane fenomeny są wykorzystywane w toku aktywności komunikacyjnej, a ekspresja werbalna z pewnością nie zawsze będzie dla nich adekwatnym substytutem. Jak słusznie odnotowuje Beth Haslett, proces komunikacji to wieloaspektowe zjawisko, zachodzace na poziomie werbalnym i niewerbalnym ${ }^{12}$. Redukcja gwarancyjnej funkcji pierwszej poprawki niewątpliwie bez dostatecznych racji uszczuplałaby - i to w nader poważnym stopniu - zakres indywidualnej swobody ekspresyjnej.

Drugi argument nawiązuje do oryginalistycznej koncepcji interpretacji konstytucyjnej, która - najogólniej rzecz ujmując - zmierza do odkrycia pierwotnego znaczenia tekstu ustawy zasadniczej. Oryginaliści przyjmuja, że wykładnia poszczególnych postanowień konstytucji powinna opierać się już to na ich rozumieniu przez ówczesnego prawodawcę (np. w zgodzie $\mathrm{z}$ jego intencjami), już to na ich pojmowaniu przez większość obywateli w chwili uchwalenia danej klauzuli; bardziej wyrafinowana wersja oryginalizmu sugeruje wyabstrahowanie $\mathrm{z}$ tak zinterpretowanej konstytucji pewnych gene-

${ }^{10}$ L. Henkin, Foreword: on drawing lines, „Harvard Law Review”, vol. 82, issue 1, s. 79.

${ }^{11}$ M.B. Nimmer, The meaning of symbolic speech under the First Amendment, „UCLA Law Review", vol. 21, issue 1, s. 33. Symboliczną naturę komunikacji werbalnej akcentuje także Zygmunt Ziembiński, w którego opinii „napis wymaga przypisania mu określonego sensu, jeśli ma być traktowany jako określona wypowiedź, a nie tylko zespół kresek sporządzonych przez drukarza czy kaligrafa", w: idem, S. Wronkowska, Z. Ziembiński, Zarys teorii prawa, Poznań 1997, s. 166.

${ }^{12}$ B. Haslett, Communication: strategic action in context, Hillsdale 1987, s. 4-5. 
ralnych zasad, które mogą być z powodzeniem zastosowane do stanów faktycznych, nieznanych w okresie ustanawiania określonych zapisów ustawy zasadniczej ${ }^{13}$. W przeświadczeniu Eugene'a Volokha, objęcie gwarancjami pierwszej poprawki przynajmniej niektórych zachowań niewerbalnych znajduje legitymację w kulturze politycznej i prawnej panującej u schyłku XVIII stulecia. Na rzecz takiego stanowiska Volokh przywołuje szereg racji. Po pierwsze, amerykański dyskurs polityczny oraz życie publiczne epoki przesiąknięte były ekspresją niewerbalna, której komunikacyjne własności pozostawały oczywiste dla uczestników społecznej konwersacji (np. palenie kukieł oraz flag z napisem „Wolność lub Śmierć”, wznoszenie tzw. totemów wolności, przyozdabianie gałęzi określonymi akcesoriami w celu skonstruowania symbolicznych drzew wolności, przyczepianie do nakryć głowy kolorystycznie zróżnicowanych wstążek desygnujących polityczne sympatie, publiczne niszczenie tekstów federalnych ustaw). Po drugie, tradycyjne dla brytyjskiego common law rozumienie terminu ,zniewaga” zakładało, że czyn ów może zostać popełniony zarówno przy użyciu komunikacji werbalnej, jak i przez posłużenie się ekspresyjnym zachowaniem (takie ujęcie zagadnienia można odnaleźć między innymi w pismach sir Edwarda Coke'a oraz sir Williama Blackstone'a). Za adekwatną egzemplifikację zniewagi uznawano na przykład tak paradygmatyczne formy ekspresyjnego zachowania, jak chociażby spalenie kukły przedstawiającej politycznego adwersarza, umieszczenie przed domem oficera armii drewnianego pistoletu (desygnującego tchórzostwo), zapalenie przed czyimś domem latarni (sugerujące, że jest to dom publiczny). Po trzecie, wypowiedzi werbalne i symboliczne były traktowane ekwiwalentnie także przez prawa dotyczące działalności wywrotowej, przepisy wymierzone w ekspresję obsceniczną i unormowania penalizujące bluźnierstwo. Po czwarte, na przykład w sprawie z 1795 r. (Respublica vs. Montgomery) strony owego postępowania zgodnie uznały wzniesienie ,totemu wolności” za odpowiednik słowa (spór dotyczył tylko kwestii, czy w tym konkretnym przypadku wolność słowa nie została nadużyta). Podobne stanowisko można zresztą odnaleźć w pismach wielu prominentnych jurystów epoki. Po piąte, wolność słowa była wówczas dość powszechnie pojmowana jako uprawnienie do ujawniania oraz proklamowania swoich przekonań, odczuć i sentymentów (a nie jedynie jako prawo do pisania i mówienia). Fakty te układają się w spójny wzór potwierdzający pogląd, że pierwsza poprawka odnosi się do co najmniej cześci zachowań ekspresyjnych (choć nie przesądzają definitywnie zakresu i charakteru takiej ochrony) $)^{14}$.

13 Por. A.B. Coan, Talking originalism, „Brigham Young University Law Review” 2009, issue 4, s. 847-873.

${ }^{14}$ E. Volokh, Symbolic expression and the original meaning of the First Amendment, „The Georgetown Law Journal” vol. 97, s. 1059-1084. Dodajmy, iż Volokh osobiście nie jest orędownikiem optyki oryginalistycznej. 
Ostatni z argumentów opiera się na aksjologicznej i celowościowej analizie pierwszej poprawki. W amerykańskim dyskursie filozoficznoprawnym wymienia się zazwyczaj cztery powody, dla których wolność słowa konstytuuje wartość zasługującą na szeroko rozumianą ochronę oraz dla których pierwsza poprawka przyjęła stosowne brzmienie. Pierwsze $\mathrm{z}$ owych usprawiedliwień posiada charakter nieinstrumentalny; poszanowanie wolności słowa jest tutaj deontologicznym dobrem, stanowiąc manifestację poszanowania przez państwo jednostkowej autonomii i konstytuując jeden z najbardziej fundamentalnych przejawów respektu państwa względem człowieka, będącego odrębnym podmiotem obdarzonym niezbywalną godnością i posiadającego podstawowe prawo do samostanowienia ${ }^{15}$. Warto nadmienić, że omawiane uzasadnienie koncentrować się może wokół uprawnień przysługujących zarówno nadawcy danego komunikatu, jak i jego odbiorcy. $Z$ jednej bowiem strony, możliwość swobodnego wyrażania przekonań i uczuć jest centralnym składnikiem egzystencji ludzi jako niezależnych podmiotów, manifestujących tym sposobem swoją osobowość ${ }^{16}$; $\mathrm{z}$ drugiej strony, ingerencja państwa, uniemożliwiająca jednostce zapoznanie się z jakimikolwiek poglądami bądź też odczuciami mogącymi przyczynić się do samodzielnego sformułowania przez nią własnego i racjonalnego (tzn. stanowiącego rezultat indywidualnego procesu myślowego) stanowiska w określonej kwestii, wymusza na człowieku dostosowanie się do opinii innych podmiotów w kwestii moralnej oceny danej aktywności komunikacyjnej i pozbawia go szansy na niezależne dojście do konkluzji w przedmiotowej sprawie ${ }^{17}$. Drugie z usprawiedliwień odnosi się przede wszystkim do kwestii epistemologicznych. Wolność słowa jest tu postrzegana jako instrument ułatwiający dojście do prawdy i pozwalający na osiągnięcie postępu w różnych dziedzinach ludzkiej aktywności (poczynając od polityki czy prawa, a kończąc na sztuce czy literaturze). Argument ten precyzyjnie odtwarza (w wypowiedzi utrzymanej ewidentnie w miltonowsko-millowskim duchu) Thomas I. Emerson: „Osoba poszukująca wiedzy i prawdy musi zapoznać się ze wszystkimi punktami widzenia w danej sprawie, musi rozważyć wszystkie alternatywy, musi przetestować swój osąd poprzez wystawienie go na konfrontację $z$ osądami przeciwnymi oraz musi uczynić pełny użytek z różnych koncepcji. Dyskusja musi być otwarta niezależnie od tego, jak pewny może wydawać się akceptowany powszechnie pogląd; wiele z naj-

${ }^{15}$ Por. R. Dworkin, Justice in robes, Cambridge 2006, s. 70.

${ }^{16}$ G.E. Carmi, Dignity-the enemy from within: a theoretical and comparative analysis of human dignity as a free speech justification, „Journal of Constitutional Law” vol. 9, s. 974; K. Greenawalt, Free speech justifications, „Columbia Law Review” vol. 89, s. 153. Jak pisze Wojciech Sadurski, swoboda wypowiedzi ,is crucial for self-fulfillment because the exercise of our capacities is only made possible through self-definition, and the determination of who we really are is impossible without open communication with our fellow human beings", w: idem, Freedom of speech and its limits, Dordrecht 1999, s. 17

${ }_{17}$ K. Greenawalt, Free speech, s. 150-152. 
szerzej aprobowanych prawd okazywało się następnie błędnymi. I odwrotnie, taką samą regułę należy zastosować niezależnie od tego, jak fałszywy lub też niebezpieczny wydaje się pogląd nowy, albowiem może on okazać się prawdziwy czy częściowo prawdziwy, a nawet jeżeli jest on w całości fałszywy, to $\mathrm{i}$ tak jego przedstawienie $\mathrm{i}$ otwarte przedyskutowanie wymusza ponowne przemyślenie oraz weryfikację poglądów ortodoksyjnych"18. Trzecie uzasadnienie odwołuje się do natury systemu demokratycznego i jest szczególnie relewantne do poglądów ojców-założycieli Stanów Zjednoczonych (w szczególności Thomasa Jeffersona oraz Jamesa Madisona). Argument ten ufundowany jest na przesłance, zgodnie z którą zasada wolności słowa, gwarantująca otrzymywanie przez obywateli kształtujących ich preferencje informacji, opinii i punktów widzenia ze zróżnicowanych źródeł, jest warunkiem sine qua non systemu deliberatywnej demokracji, w którym decyzje polityczne (w największym możliwym stopniu) odzwierciedlają poglądy i życzenia opinii publicznej ${ }^{19}$. W tym ujęciu swoboda wypowiedzi i wolna wymiana idei pozwala jednostkom na skorzystanie w pełni z ich aktywnej, pozytywnej wolności do suwerennego kształtowania porządku społeczno-politycznego ${ }^{20}$. Zgodnie z owa perspektywa, pierwsza poprawka ochrania przede wszystkim autentyczność oraz integralność debaty publicznej ${ }^{21}$ (w zakresie obejmującym nie tylko ekspresję stricte polityczna, ale także wypowiedzi naukowe, artystyczne, filozoficzne itp.). Argumenty z prawdy oraz z demokracji maja charakter konsekwencjalistyczny, koncentrując się na społecznych pożytkach płynących $\mathrm{z}$ respektowania swobody wypowiedzi. Ostatni sposób legitymizacji wolności słowa wiąże ją zaś z traktowanym w kategoriach nieinstrumentalnych postulatem stworzenia tolerancyjnego społeczeństwa, którego naczelną zasadę stanowi ideowy pluralizm ${ }^{22}$.

Ta zwięzła rekapitulacja aksjologicznych sądów uprawomocniających regułę swobody wypowiedzi pozwala na sformułowanie konkluzji, zgodnie $\mathrm{z}$ którą racje moralne i etyczne, przemawiające za ochroną wolności komunikowania się przy użyciu ekspresyjnych zachowań, są de facto jednakowe z argumentami legitymizującymi zasadność zagwarantowania wolności ekspresji

18 T.I. Emerson, The system, s. 6-7. Wydaje się, że pojęcie „prawda” powinno być tutaj traktowane w szerszych aniżeli arystotelesowskie kategoriach (jako zgodność opisu z rzeczywistością), albowiem również wolność wygłaszania opinii - tj. zdań niepodlegających ściśle rozumianej weryfikacji lub falsyfikacji opartych na obiektywnych kryteriach - przyczynia się do poszerzenia ludzkiej wiedzy o otaczającej nas rzeczywistości.

${ }^{19}$ C.R. Sunstein, Democracy and the problem of free speech, New York 1995, s. 18-19, 244.

${ }^{20}$ S. Breyer, Active liberty: interpreting our democratic Constitution, New York 2005, s. 15, 42.

R.C. Post, Reconciling theory and doctrine in First Amendment jurisprudence, w: Eternally vigilant: free speech in the modern era, ed. by L.C. Bollinger and G.R. Stone, Chicago 2002 , s. $166-167$.

${ }^{22}$ Głównym orędownikiem tej koncepcji na gruncie amerykańskim jest Lee C. Bollinger. Por. idem, The tolerant society: freedom of speech and extremist speech in America, New York 1986, s. $107,111,116-120$. 
werbalnej. Rzeczona tożsamość wynika z bliskiego związku obydwu fenomenów z podstawową regułą wolnego społeczeństwa, jaką jest wolność myśli oraz sumienia. Swoboda wypowiedzi niewerbalnej, analogicznie jak ekspresji werbalnej, konstytuuje istotny element indywidualnej autonomii, samorealizacji i samostanowienia; komunikacja niewerbalna może stanowić manifestację ideologicznych czy politycznych przekonań bądź preferencji, których swoboda głoszenia należy do fundamentalnych kanonów ustroju liberalno-demokratycznego; ekspresyjne zachowania przyczyniać się mogą-zgodnie $z$ miltonowskim czy millowskim paradygmatem - do lepszego zrozumienia otaczającej nas rzeczywistości, nawet jeśli są bulwersujące bądź kontrowersyjne; w równym stopniu jak do słowa pisanego czy mówionego odnosi się do nich wymóg tolerancji.

Uznając wymienione powyżej argumenty za przekonujące, Sąd Najwyższy Stanów Zjednoczonych konsekwentnie - co najmniej od 1931 r. - obejmował niektóre zachowania niewerbalne gwarancjami pierwszej poprawki ${ }^{23}$. Katalog takich przedmiotów ochrony jest jednak zróżnicowany. W orzecznictwie Sądu Najwyższego możemy wyróżnić trzy kategorie relewantnych z perspektywy klauzuli wolności słowa rodzajów aktywności niewerbalnej. Do pierwszej z nich możemy zakwalifikować ,zachowania na tyle ograniczone w formie, aby były konieczne dla przekazania określonej idei"24. Ten rodzaj aktywności jest traktowany przez Sąd Najwyższy jako „czyste słowo" (pure speech), czyli w sposób całkowicie tożsamy z ekspresją werbalna. Druga kategoria obejmuje tak zwany speech plus, czyli specyficzny złożony rodzaj wypowiedzi, na która składają się konceptualnie odrębne słowo i zachowanie. Chodzi tutaj, przykładowo, o demonstrowanie z określonymi hasłami, rozdawanie ulotek bądź pikietowanie. Trzecia grupa zachowań to tak zwane wypowiedzi symboliczne, czyli zachowania niewerbalne, które wyrażają określone poglądy, idee bądź też emocje działającego podmiotu. W toku orzecznictwa Sąd Najwyższy USA zaliczył do grupy wypowiedzi symbolicznych między innymi takie rodzaje aktywności, jak wywieszanie czerwonej flagi symbolizującej poparcie dla ideologii komunistycznej25, odmowa oddawania honorów fladze państwowej przez ucznia szkoły publicznej w toku zajęć edukacyjnych ${ }^{26}$, milcząca odmowa opuszczenia przez czarnoskórego obywatela biblioteki poddanej regułom segregacji rasowej ${ }^{27}$, noszenie przez ucznia szkoły publicznej podczas zajęć czarnej opaski na ramieniu w celu oprotestowania polityki Stanów Zjednoczonych w Wietnamie ${ }^{28}$, niszczenie karty powołania do wojska w proteście poli-

${ }^{23}$ Oczywiście poszczególni sędziowie kładli nacisk na odmienne rozumowania fundujące to założenie.

${ }^{24}$ Merriam-Webster's dictionary of law, Springfield 1996, s. 398.

25 Por. Stromberg vs. California, 283 U.S. Reports 359.

26 Por. West Virginia State Board of Education vs. Barnette, 319 U. S. 624.

27 Por. Brown vs. Louisiana, 383 U.S. Reports 131.

${ }^{28}$ Por. Tinker vs. Des Moines School District, 393 U.S. Reports 503. 
tycznym ${ }^{29}$, spędzenie noclegu w parku narodowym w celu udramatyzowania trudnego losu osób bezdomnych ${ }^{30}$, palenie krucyfiksów ${ }^{31}$, a nawet erotyczny taniec nago ${ }^{32}$. Do owej kategorii należy zaliczyć również ekspresyjne profanowanie flagi państwowej, co Sąd Najwyższy uczynił w serii rozstrzygnięć wydanych w latach 80 . i 90. (choć, jak przekonamy się niżej, przy głośnym sprzeciwie części sędziów i opinii publicznej).

Przed przystapieniem do prezentacji rozstrzygnięcia Sądu Najwyższego w sprawie Texas vs. Johnson należy przywołać standardy orzecznicze, które Sąd Najwyższy zastosował przy ewaluacji przedmiotowego casusu. Istotne znaczenie posiadają tutaj przede wszystkim trzy instrumenty analityczne. Pierwszy z nich - tak zwany test Spence'a - pozwala ocenić, czy określone zachowanie niewerbalne w ogóle zasługuje na status „słowa” w rozumieniu pierwszej poprawki. Zgodnie ze wskazanym standardem, do kategorii ekspresji symbolicznej możemy zaliczyć działanie lub zaniechanie, w którym dostrzegalny jest zamiar wyrażenia skonkretyzowanego przekazu, a uwzględniając panujące okoliczności, istnieje wysokie prawdopodobieństwo, że przekaz ten będzie zrozumiany przez jego odbiorców. Standard koncentruje się więc na komunikacyjnej intencji mówcy oraz na kwestii, czy jego przekaz będzie faktycznie percypowany"33. Jeżeli inwestygacja uniemożliwia pozytywną odpowiedź na którekolwiek z powyższych pytań, to dane zachowanie nie będzie w ogóle chronione przez klauzulę wolności słowa. Drugi z testów to tak zwany standard O'Briena, który pozwala uprawomocnić z konstytucyjnego punktu widzenia prawne ograniczenie swobody komunikacji niewerbalnej, jeśli: 1) uchwalenie danej regulacji generalnie mieści się w kompetencjach władzy publicznej; 2) jej wprowadzenie pomaga w urzeczywistnieniu istotnego ( $s u b$ stantial) interesu rządowego; 3) interes ten nie jest związany z thumieniem wolności słowa; 4) akcydentalny ciężar nałożony na pierwszą poprawkę nie jest większy niż jest to niezbędne do realizacji tegoż interesu ${ }^{34}$. Spośród rzeczonych warunków najistotniejsze znaczenie posiada postanowienie trzecie, które - najogólniej rzecz ujmując (precyzyjna eksplikacja tego warunku budzi poważne kontrowersje w doktrynie czy praktyce jurydycznej) - wyklucza dopuszczalność ograniczenia wolności komunikacji symbolicznej z uwagi na jej treść, ideowe przesłanie lub światopogląd głoszącego ją podmiotu. Relewant-

${ }^{29}$ Por. Stany Zjednoczone vs. O'Brien, 391 U.S. Reports 367

${ }^{30}$ Por. Clark v. Community for Creative Non-Violence, 468 U.S. Reports 268.

${ }_{31}$ Por. R.A.V. vs. St. Paul, 505 U.S. Reports 377; Virginia vs. Black et al., 538 U.S. Reports 343.

32 Por. Barnes vs. Glen Theatre, Inc., 501 U.S. Reports 560; City of Erie vs. Pap's A. M., 529 U.S. Reports 277.

${ }^{33}$ P. Siegel, Communication law in America, Lanham 2007, s. 82. Test ten został po raz pierwszy wprowadzony w wyroku SN w sprawie Spence vs. Washington, 418 U.S. Reports 405 . Szerzej na temat obydwu warunków standardu Spence'a zob. zwłaszcza Note (b.a.), Symbolic conduct, "Columbia Law Review", vol. 68, s. 1109-1118 (co interesujące, tekst jest formulowany z pozycji de lege ferenda).

${ }^{4}$ United States v. O'Brien, 391 U.S. Reports 377. 
ny interes musi zatem mieć charakter nieekspresyjny. Zgodne z konstytucją jest na przykład skazanie podpalacza krucyfiksu za spowodowanie tym działaniem niebezpieczeństwa wybuchu pożaru (jeśli oczywiście ocena ta jest faktualnie prawomocna); natomiast penalizacja tej aktywności na podstawie hipotetycznego przepisu zabraniającego głoszenia poglądów rasistowskich czy formułowania „mowy nienawiści” kolidowałaby z pierwszą poprawką. Jeżeli dana regulacja nie może zostać usankcjonowana w oparciu o test O'Briena, Sąd Najwyższy stosuje trzeci ze wspomnianych testów - standard surowego nadzoru sędziowskiego (strict judicial scrutiny), zgodnie z którym dane unormowanie jest niezgodne $\mathrm{z}$ ustawą zasadniczą, chyba że realizuje fundamentalny interes rządowy, jest wąsko ujęte (tzn. wymierzone w ekspresję, która narusza przedmiotowy interes), a potencjalna alternatywna norma nakładająca mniejsze ciężary na prawa czy wolności obywatelskie nie pozwala w dostatecznym stopniu na urzeczywistnienie wskazanego celu ${ }^{35}$. W konkluzji należy dodać, że ocenie Sądu Najwyższego podlega zarówno generalna i abstrakcyjna norma prawna zawarta $w$ określonym akcie normatywnym, jak i jej aplikacja, będąca wynikiem subsumcji takiej normy do konkretnego stanu faktycznego.

Wyroki Sądu Najwyższego USA w sprawach dotyczących wypowiedzi symbolicznych bardzo często odnosiły się do zagadnień nader doniosłych i kontrowersyjnych ze społecznego, ideowego lub politycznego punktu widzenia. Prawo do gloryfikowania doktryny komunistycznej, granice wymogu zachowania patriotycznej lojalności w czasie wojny, prawo do publicznej ekspresji sprzeciwu wobec uznawanej za niewłaściwa polityki państwa (segregacja rasowa i militarne zaangażowanie Stanów Zjednoczonych w Wietnamie), istnienie konstytucyjnego uprawnienia do propagowania rasizmu, zakres regulacyjnych kompetencji władzy publicznej w relacji do wypowiedzi o charakterze erotycznym - normatywna ewaluacja tych kwestii nie stanowiła jedynie przedmiotu ezoterycznej i erudycyjnej refleksji praktyków oraz teoretyków prawa, ale znajdowała również oddźwięk w szerszych kręgach społeczeństwa. Wydaje się jednak, że żaden ze wskazanych tematów nie wzbudził tak silnych emocji społecznych jak zagadnienie dopuszczalności profanowania flagi państwowej w celach ekspresyjnych. Choć numeryczna przewaga w debacie toczonej głównie na przełomie lat 80. i 90. XX w. znajdowała się zdecydowanie po stronie orędowników penalizacji tego postępku, to jednak głos zwolenników dekryminalizacji podobnych działań także był dobrze słyszalny. Warto dodać, że w dyskusji tej przeplatała się płaszczyzna deskryptywna i postulatywna: adwokaci karania takich czynów zwykle utrzymywali, że ewentualne sankcje nie kolidują co do zasady z pierwszą poprawka; ich oponenci sądzili zaś, że klauzula wolności słowa uniemoźliwia penalizację ekspresyjnego bezczeszczenia (desecration) sztandaru państwowego.

${ }^{35}$ Por. np. R. J. Steamer, Contemporary Supreme Court directions in civil liberties, „Political Science Quarterly", vol. 92, s. 433. 
Polemika ta konstytuowała jeden z kluczowych frontów amerykańskiej wojny kulturowej. Intensywność sporu wynikała w dużym stopniu ze szczególnego miejsca, jakie w kulturze politycznej USA zajmuje flaga państwowa. Nie sposób polemizować z poglądem, że flaga Stanów Zjednoczonych stanowi najważniejszy wspólnotowy symbol dla amerykańskiego społeczeństwa ${ }^{36}$. Stąd też orędownicy objęcia jej prawną ochroną często zarzucali swoim adwersarzom niedostatki patriotyzmu, brak lojalności wobec własnej społeczności, żywienie pogardy dla wartości cenionych przez współobywateli, promowanie czy stymulowanie moralnego indyferentyzmu itp. Osoby zajmujące przeciwne stanowisko niejednokrotnie formułowały równie krytyczne oceny w stosunku do oponentów, piętnując ich domniemaną idolatrię, fetyszyzujący stosunek do symboli narodowych, nader symplicystyczną postawę w stosunku do patriotyzmu czy wreszcie podważanie aksjologicznej podwaliny Stanów Zjednoczonych, która jest pierwsza poprawka ${ }^{37}$.

Przedmiotowa debata społeczna bez wątpienia stanowiła refleks ogólniejszych sporów doktrynalno-politycznych. Z jednej strony można bez trudu skonceptualizować analizowaną dyskusję jako reprezentatywny przejaw klasycznego konfliktu między liberałami (bądź libertarianami) a konserwatysta$\mathrm{mi}$. Z pewnością traktowanie prawa do zbezczeszczenia flagi jako desygnatu gwarantowanej pierwsza poprawką swobody wypowiedzi wynika $\mathrm{z}$ afirmacji możliwie szerokiej interpretacji zasady wolności słowa, z uznawania jednostkowej autonomii za fundamentalną wartość i z krytycznego stosunku do arbitralnej interwencji państwa (nawet motywowanej najszlachetniejszymi przesłankami) w obszar indywidualnych uprawnien ${ }^{38}$. Z kolei postulat objęcia sztandaru państwowego ochrona prawa dobrze komponuje się z konserwatywną aprobatą tradycji, autorytetu, hierarchii oraz moralizmu w polityce. $Z$ drugiej strony przedmiotową debatę można także ująć w kategoriach opozycji między paradygmatem liberalnym a komunitarystycznym. Jak przekonująco dowodzi Robert C. Post, spór na temat penalizacji profanacji flagi odzwierciedla jeden z podstawowych dylematów współczesnego prawodawcy (nie tylko amerykańskiego), który zmuszony jest do opowiedzenia się bądź to za uwzględnianiem przez dany porządek normatywny wspólnotowo zakorzenionych tożsamości obywatelskich oraz substancjalnie definiowanych koncepcji samopojmowania się określonej społeczności, bądź to za „hermeneutycznym projektem responsywnej demokracji", w której autonomiczne jednostki maja prawo do „kreowania własnych urządzeń społecznych” bez konieczności brania pod uwage obowiązków wynikających z faktu egzystencji w konkretnej wspólnocie. Wybór między niekaralnością a karalnością desakralizacji sztan-

\footnotetext{
${ }^{36} \mathrm{~W}$. Lloyd Warner, The living and the dead; a study of the symbolic life of Americans, New Haven 1959, s. 37.

37 Por. P. Brady, Flag burning should be banned i M. Kinsley, Flag burning should not be banned, w: Should there be limits to free speech?, ed. by L. Egendorf, San Diego 2002, s. 70-76.

${ }^{38}$ Por. R. West, Progressive constitutionalism, Durham 1994, s. 105-107.
} 
daru jest zatem refleksem ogólniejszego filozoficznopolitycznego problemu. Rozstrzygnięcie tegoż dylematu wymaga opowiedzenia się za formalistycznym lub substancjalnym modelem demokracji i stawia ustawodawcę przed koniecznością odpowiedzi na pytanie, czy doktryny prawne powinny być ustanawiane w społecznej próżni (po to, by kreować „przestrzeń dla autonomicznych jednostek niezależnie kształtujących stosunki społeczne”), czy też raczej powinny być pochodną wspólnotowych i społecznie zakorzenionych praktyk, których celem jest podtrzymywanie norm postępowania wspierających i definiujących tożsamość Amerykanów w imię aksjologicznie nieneutralnej koncepcji dobra ogółu, z którą identyfikuje się większość obywateli ${ }^{39}$. Prawna decyzja Sądu Najwyższego musiała przeto zawierać elementy odnoszące się do takich ideowych kontrowersji.

Sprawa Texas vs. Johnson nie była pierwszym sporem zawisłym przed obliczem Sądu Najwyższego, który dotyczył unormowań regulujących kwestię właściwego obchodzenia się ze sztandarem państwowym. Analizując wcześniejsze rozstrzygnięcia, można już dostrzec stopniową zmianę orzeczniczego paradygmatu $\mathrm{w}$ tej materii. Zgodnie $\mathrm{z}$ tradycyjnym ujęciem, uprawnienie władz publicznych do karania profanacji flagi było właściwie nieproblematyczne. Egzemplifikacja tej postawy jest wyrok z roku 1907 (Halter vs. Nebraska ${ }^{40}$ ), dotyczący wykorzystania motywu flagi w działalności gospodarczej do celów reklamowych, gdzie Sąd Najwyższy uznał ochronę sztandaru nie tyle za prawo, co wręcz za obowiązek legislatywy. Dopiero pod koniec lat 60 . judykatura zaczęła $\mathrm{z}$ większym sceptycyzmem traktować penalizacyjną aktywność państwa w kontekście bezczeszczenia flagi, czego następstwem były trzy wyroki Sądu Najwyższego, podważające konstytucyjność skazania osób wykorzystujących sztandar do politycznych manifestacji bądź celów artystycznych. Uzasadnieniem tych decyzji były już to błędy proceduralne występujące w postępowaniu w niższych instancjach ${ }^{41}$, już to niedostatecznie precyzyjne sformułowanie przepisów stanowiących podstawę normatywną danego procesu $^{42}$, już to szczególny charakter i okoliczności kryminalizowanego czynu ${ }^{43}$. Wspólną - i znacząca - cechą przedstawionych rozstrzygnięć było przyjęcie tezy, że pierwsza poprawka narzuca władzy publicznej określone ograniczenia

${ }^{39}$ R.C. Post, Between democracy and community: the legal constitution of social form, w: Democratic community, ed. by J.W. Chapman and I. Shapiro, New York 1993, s. 177-178; idem, Constitutional domains: democracy, community, management, Cambridge 1995, s. 191-192.

40205 U.S. Reports 34. Orzeczenie to zapadło w zamierzchłych z perspektywy sq̨downictwa konstytucyjnego czasach (głęboka deferencja judykatury wobec decyzji ustawodawcy, niepewność co do stosowalności pierwszej poprawki do regulacji stanowych itp.); stąd jego współczesna relewantność wydaje się raczej skromna. Niemniej jednak treść uzasadnienia wyroku jest bardzo sugestywna, ponieważ odzwierciedla tradycyjne pojmowanie roli oraz charakteru flagi państwowej, obowiązujące przez wiele następnych dekad w amerykańskiej jurysprudencji.

${ }^{41}$ Street vs. New York, 394 U.S. Reports 576.

42 Smith vs. Goguen, 415 U.S. Reports 566.

43 Spence vs. Washington, 418 U.S. Reports 405. 
w odniesieniu do karania ekspresyjnego profanowania flagi. Jednakże wyroki te nie przesądzały definitywnie, czy pragnienie zachowania flagi narodowej jako nieskażonego symbolu, stanowiącego manifestację uniwersalistycznie pojmowanego amerykańskiego ideału, to uzasadniona konstytucyjnie motywacja ograniczenia swobody wypowiedzi ${ }^{44}$. W sposób konkluzywny i ultymatywny Sąd Najwyższy stawił czoło temu zagadnieniu dopiero w 1989 r., podczas rozpoznawania sprawy Texas vs. Johnson.

Rozpoczą́ trzeba od prezentacji stanu faktycznego i drogi instancyjnej sprawy $^{45}$. Podczas konwencji Partii Republikańskiej, która odbyła się w 1984 r. w Dallas, niejaki Gregory Lee Johnson uczestniczył w demonstracji wymierzonej przeciw polityce prowadzonej przez administrację prezydenta Ronalda Reagana. Manifestanci przemaszerowali ulicami miasta, skandując stosowne slogany i oprotestowując „agresywne” postępowanie Stanów Zjednoczonych w sferze stosunków międzynarodowych, które miało rzekomo prowokować wojnę nuklearną. Demonstracja nie przebiegała bynajmniej w pełni spokojnie (m.in. manifestanci spryskiwali sprayem budynki oraz wywrócili kilka doniczek z kwiatami). Sam Johnson nie brał udziału w tych ostatnich wydarzeniach, ale przyjął od jednego z demonstrantów flagę zerwaną ze stojącego w miejscu publicznym masztu. Kiedy protestujący dotarli przed ratusz, Johnson rozwinął sztandar, zanurzył go w nafcie oraz podłożył ogień. Gdy flaga płonęła, manifestanci skandowali wers mówiący o opluwaniu barw narodowych ${ }^{46}$. Choć w toku manifestacji nikt nie został ranny, a protestujący nie posługiwali się groźbami karalnymi, to jednak prokuratura zdecydowała się wnieść przeciw Johnsonowi akt oskarżenia. Podstawą prawną był przepis teksańskiego kodeksu karnego, który zabraniał desakralizacji otoczonego czcią obiektu (w tym flagi państwowej). Definicja legalna terminu „desakralizacja” obejmowała uszkadzanie bądź niewłaściwe traktowanie jakiegoś przedmiotu w taki sposób, że osoba działająca jest w pełni świadoma, iż jej czyn poważnie obrazi uczucia faktycznych lub potencjalnych obserwatorów ${ }^{47}$. Johnson został skazany w pierwszej instancji na rok pozbawienia wolności i grzywnę w wysokości 2 tys. dolarów. Wyrok uchylono dopiero w trzeciej instancji, kiedy to stanowy sąd, zajmujący się apelacjami w obszarze prawa karnego, uznał, że zachowanie Johnsona, jako wypełniające znamiona wypowiedzi symbolicznej, było objęte zakresem normowania pierwszej poprawki, a aplikacja wspomnianego wyżej przepisu do tego konkretnego czynu łamie ustawę zasadniczą. Sąd stanowczo zakwestionował wszelkie argumenty wysuwane przez prokuraturę, powołującą się na potrzebę ochrony symbolicznego znaczenia flagi oraz

${ }^{44}$ Zob. J.K. Lieberman, Free speech, free press, and the law, New York 1980, s. 63

Zob. np. D.T. Eversole, $A$ voyage through murky waters: assessing flag misuse prohibitions in the wake of Texas v. Johnson, 109 S. Ct. 2533 (1989), „Florida State Law Review”, vol. 17, s. $871-875$.

\footnotetext{
46 "America, the red, white, and blue, we spit on you".

47 Kilku świadków rzeczywiście zeznało, że poczuli się czynem Johnsona poważnie obrażeni.
} 
wymogi porządku publicznego. Po złożeniu odwołania przez Texas, sprawa zawisła przed Sądem Najwyższym USA, który zatwierdził rozstrzygnięcie poprzednio rozpatrującego casus sądu. Wyrok zapadł minimalną różnicą głosów (pięć do czterech), a jego uzasadnienie sporządził sędzia William Brennan, jedna $\mathrm{z}$ ikon liberalnie zorientowanej jurysprudencji. W składzie większości znaleźli się jednak również sędziowie o zdecydowanie konserwatywnych inklinacjach, jak Anthony Kennedy oraz Antonin Scalia.

Przeanalizujmy podstawowe tezy uzasadnienia. Na początku swoich wywodów sędzia wprost zadeklarował, że skuteczność powołania się przez podsądnego na pierwszą poprawkę uzależniona jest od możliwości zakwalifikowania jego czynu jako wypowiedzi symbolicznej. Innymi słowy, orzeczenie nie miało odnosić się do kwestii dopuszczalności prawnej „ochrony flagi w ogóle", ale tylko do zagadnienia, czy i w jakim stopniu polegające na bezczeszczeniu sztandaru działanie ekspresyjne zasługuje na immunitet ${ }^{48}$. Brennan jednoznacznie stwierdził, że czyn Johnsona był w dostatecznym stopniu nasycony elementami natury komunikacyjnej, by pozostawać w orbicie oddziaływania klauzuli wolności słowa. Kryterium pozwalającym na taką klasyfikację było pozytywne przejście testu Spence’a. W przeświadczeniu sędziego „spalenie flagi przez Johnsona było fragmentem - a właściwie punktem kulminacyjnym - politycznej demonstracji, która odbyła się w czasie konwencji partii republikańskiej, ponownie nominującej Ronalda Reagana na urząd Prezydenta. Ekspresyjna i jawnie polityczna istota tego zachowania była zarówno zamierzona, jak i w sposób klarowny rozpoznawalna". Według Brennana, wniosek o komunikacyjnym charakterze czynu Johnsona może być ponadto uzasadniony (obok powyższej analizy kontekstualnej, dowodzącej istnienia po stronie podsądnego oczywistego zamiaru wyrażenia skonkretyzowanego przekazu, który z dużym prawdopodobieństwem mógł być zrozumiały dla odbiorców) poprzez przypomnienie symbolicznego znaczenia sztandaru państwowego (który reprezentuje naród „w takim samym stopniu, co kombinacja liter występująca w słowie «Ameryka»"), przywołanie przedstawionej w toku procesu przez oskarżonego autointerpretacji swego zachowania właśnie w kategoriach politycznego protestu i nadanie odpowiedniego znaczenia faktowi, że Teksas, przynajmniej dla celów postępowania przed Sądem Najwyższym, nie zakwestionował kwalifikacji przedmiotowego czynu jako zachowania ekspresyjnego. Te ostatnie przesłanki miały jednak tylko charakter posiłkowy w zestawieniu z argumentem z testu Spence'a. Wydaje się, że brennanowskie ujęcie zagadnienia zostało zaakceptowane przez zdecydowaną większość

48 T.L. Tedford, D.A. Herbeck, Freedom of speech in the United States, State College 2001, s. 286. Jak podkreślał Brennan, SN nie zajmuje się kwestią zgodności z konstytucją hipotetycznego skazania jakiegoś zmęczonego podróżnika, który ciągnie za sobą flagę po ubłoconej ziemi bez zamiaru ekspresyjnego. 
komentatorów ${ }^{49}$. Nawet orędownicy restrykcyjnej interpretacji pierwszej poprawki à propos bezczeszczenia sztandaru zazwyczaj nie kwestionowali ekspresyjnego charakteru zachowania Johnsona; spór dotyczył zaś kwestii czy jego „słowo" (wypowiedź symboliczna) zasługuje na konstytucyjną protekcję.

W moim przekonaniu, pogląd Brennana jest zasadniczo poprawny oraz co być może najważniejsze - dobrze zakorzeniony w dotychczasowych precedensach Sądu Najwyższego. Warto jednakże wskazać, że w debacie publicznej pojawiły się też głosy odmienne. Refutacja brennanowskiej optyki opierała się zwykle jednej z czterech dystynktywnie odrębnych - acz niewykluczających się wzajemnie - linii argumentacyjnych. Zwolennicy pierwszej z nich akceptują wprawdzie test Spence'a jako kryterium pozwalające odróżniać „słowo” od ,nie słowa”, ale utrzymuja przy tym, że spalenie sztandaru nie spełnia drugiego z warunków owego standardu, ponieważ jest właściwie beztreściowym i pozbawionym konkretnego znaczenia odpowiednikiem krzyku lub też posłużenia się ustawionym na maksymalny poziom głosu megafonem ${ }^{50}$. Drugie ujęcie nawiazzuje do oryginalistycznej teorii wykładni ustawy zasadniczej i pierwotnego rozumienia pierwszej poprawki. Jak dowodzi niedoszły sędzia Sądu Najwyższego Robert H. Bork, potraktowanie przez judykaturę profanacji flagi jako wypowiedzi symbolicznej stanowi manifestację radykalnego sędziowskiego aktywizmu, odrywającego jurydyczne rozstrzygnięcia od faktycznego tekstu aktów normatywnych oraz intencji ustawodawcy, wyjmującego istotne kulturowo-polityczne decyzje z „rąk obywateli” oraz wczytującego osobiste preferencje i idiosynkrazje jurystów do przepisów prawnych ${ }^{51}$. Trzecia koncepcja, promowana na przykład przez Erica Rasmusena, odwołuje się do ekonomicznej analizy prawa. W jego opinii, desakralizacja flagi jest aktywnością analogiczną do zanieczyszczania środowiska, albowiem działania te powoduja u odbiorców przekazu określone koszty zewnętrzne. Rasmusen akceptuje tezę, że podobne rozumowanie można przeprowadzić w stosunku do każdej obraźliwej (a zatem narzucającej koszty) wypowiedzi, co pozbawiałoby pierwszą poprawkę jakiegokolwiek znaczenia. Przekonuje jednak, że bezczeszczenie flagi jest wyraźnie odmienne od innych typów ekspresji, ponieważ: 1) obraź-

49 Por. np. K. Greenawalt, Fighting words: individuals, communities and liberties of speech, Princeton 1995, s. 30-31; M.V. Tushnet, The flag-burning episode: an essay on the Constitution, "University of Colorado Law Review" vol. 61, s. 41-42; P.M. Tiersma, Nonverbal communication and the freedom of , speech", „Wisconsin Law Review” 1993, s. 1569-1571.

50 Por. R. J. Goldstein, Flag burning \& free speech: the case of Texas v. Johnson, Lawrence 2000 , s. 198-199.

Zob. R. Bork, Introduction, w: „A country I do not recognize”: the legal assault on American values, ed. by R.H. Bork, Stanford 2005, s. XXVI; idem, Slouching towards Gomorrah: modern liberalism and the American decline, New York 1996, s. 96, 108-109, 148; idem, The tempting of America: political seduction of the law, New York 1990, s. 143, 160-163. Por. także m.in. E. Fox-Genovese, Feminism without illusions: a critique of individualism, Chapel Hill 1991, s. 111; G.L. McDowell, The Supreme Court has dictated the meaning of the Bill of Rights, w: The Bill of Rights: opposing viewpoints, ed. by W. Dudley, San Diego 1994, s. 260. 
liwość słów częstokroć jest incydentalna, podczas gdy samym celem desakralizacji jest urażanie innych osób; 2) słowa są czasami, w przeciwieństwie do palenia flagi, adresowane nie do krytykowanych podmiotów, ale do neutralnych adresatów; 3) słowa zwykle zmierzają do zakomunikowania jakiegoś przekazu, podczas gdy desakralizacja tylko obraża; 4) posługiwanie się słowem nie skutkuje fizyczną destrukcją żadnego przedmiotu; 5) nawet obraźliwe wypowiedzi werbalne mogą wywołać pozytywne eksternalności, gdyż generowanie i przekazywanie jakichkolwiek (choćby obraźliwych) informacji jest społecznie użyteczne. Tymczasem bezczeszczenie flagi powoduje nader skromne korzyści zewnętrzne, a jego zakaz - prowadzący w konsekwencji do zastappienia desakralizacji słowem - przynosi ogólny wzrost użyteczności (zgodnie z zasadami dotyczącymi tradycyjnych form komunikacji) ${ }^{52}$. Ostatnią ze wspomnianych wyżej czterech konstrukcji teoretycznych, stanowiących wyraz krytycyzmu wobec supozycji Brennana, przedstawia konserwatywny komentator Walter Berns, którego zdaniem celem pierwszej poprawki jest ochrona wyłącznie racjonalnej oraz deliberatywnej konwersacji społecznej, a nie dowolnej emanacji ekspresyjnych intencji danego podmiotu ${ }^{53}$. Niezależnie od ocen dotyczących zasadności czy wewnętrznej koherencji przywołanych tutaj alternatywnych wobec brennanowskiego ujęć, jedna kwestia pozostaje niewątpliwa: aprobata któregokolwiek z tych stanowisk z konieczności pociagnęłaby za sobą konieczność negacji utrwalonej linii precedensów Sądu Najwyższego w sprawie wypowiedzi symbolicznych. Trudno tedy dziwić się, że Sąd Najwyższy nie był skłonny wybrać takiej ścieżki postępowania.

Przesądzenie o ekspresyjnym charakterze postępku Johnsona nie determinowało jeszcze decyzji o udzieleniu mu konstytucyjnej ochrony. W świetle rozlicznych wyroków Sądu Najwyższego, dotyczących klauzuli wolności słowa, Sąd Najwyższy hipotetycznie dysponował raczej szeroką paletą możliwości wyboru, pozwalających uznać skazanie Johnsona (na podstawie rozmaitych przesłanek) za zgodne z ustawą zasadniczą. Brennan nie skorzystał jednakże z żadnej $z$ takich alternatyw. Najprostszy sposób stanowiłoby tutaj uznanie postępku Johnsona za wypowiedź pozostającą w ogóle poza sferą oddziaływania klauzuli wolności słowa. W grę wchodziłoby zakwalifikowanie ekspresyjnego spalenia flagi jako „fighting word” - obelżywego wyzwiska, którego użycie może sprowokować odbiorców do fizycznego odwetu ${ }^{54}$. Brennan lapidarnie skrytykował tę propozycję, konstatując stanowczo, że ,żaden rozsądny świadek zdarzenia nie potraktowałby wyrażenia przez Johnsona swojego ogólnego niezadowolenia $\mathrm{z}$ polityki rządu federalnego jako bezpośredniej osobistej zniewagi lub jako prowokacji do wymiany ciosów". Drugą możli-

$5:$ E. Rasmusen, The economics of desecration: flag burning and related activities, ,Journal of Legal Studies" vol. 27, s. s. 248-251, 259-260.

${ }^{53}$ W. Berns, Making patriots, Chicago 2001, s. 139-141.

${ }^{54}$ Por. Chaplinsky vs. State of New Hampshire, 315 U.S. Reports 568; Cohen vs. Califomia, 403 U.S. Reports 15. 
wością było uznanie teksańskiego przepisu za regulację spełniającą standardy zawarte w teście O'Briena (tj. nakładająca tylko akcydentalne brzemiona na ekspresję). Kluczowym elementem tej ewaluacji musiałoby być oczywiście zidentyfikowanie istotnego interesu rządowego niezwiązanego $\mathrm{z}$ thumieniem wolności słowa, którego realizacji służyłoby skazanie Johnsona. Pełnomocnicy Teksasu powoływali się w tym aspekcie na dwie wartości. Pierwszą z nich była potrzeba ochrony flagi jako symbolu Ameryki i narodowej jedności. Brennan w ultymatywnym tonie stwierdził, że ,rządowy interes polegający na zabezpieczaniu wyjatkowej symbolicznej roli sztandaru [...] jest bezpośrednio związany z ekspresją w kontekście czynu" popełnionego przez Johnsona. Powołując się na wskazany interes, Teksas wyraża bowiem de facto obawę, że tolerowanie takich zachowań „może skłonić obywateli albo do przyjęcia tezy, jakoby flaga nie reprezentowała Ameryki bądź narodowej jedności, ale raczej odzwierciedlała inne, mniej pozytywne, wartości, albo do uznania, że reprezentowane przez flagę wartości tak naprawdę nie istnieją, tj. że nasz naród jest podzielony. Takie lęki moga pojawić się tylko wtedy, gdy sposób obchodzenia się z flagą komunikuje określony przekaz; dlatego sa związane $\mathrm{z}$ thumieniem swobodnej ekspresji”. Drugi ze wskazanych nieekspresyjnych interesów polegałby na ochronie porządku publicznego. W tym kontekście Brennan podkreślał, że zachowanie podsądnego: 1) nie spowodowało żadnych zaburzeń porządku, 2) nie groziło wywołaniem takich zaburzeń oraz 3) najprawdopodobniej, w świetle zeznań złożonych przez świadków wydarzenia, nie byłoby w stanie sprowokować odbiorców przekazu do gwałtownych reakcji. Sędzia wskazywał również, że zawarta w ustawie zasadniczej ochrona wolności wypowiedzi przysługuje również ekspresji kontrowersyjnej czy obraźliwej (i wtedy okazuje się najcenniejsza). Brennan podkreślał bowiem, że na gruncie pierwszej poprawki niedopuszczalne jest blankietowe zakazanie określonych wypowiedzi ze względu na fakt, że ,istnieje prawdopodobieństwo, iż ich poważnie obrażeni odbiorcy naruszą porządek". Jeśli podstawową funkcją zasady wolności słowa jest stymulowanie debaty (także poprzez wywoływanie intelektualnego niepokoju, powodowanie niezadowolenia $z$ istniejącej rzeczywistości czy wzbudzanie gniewu), to w sposób naturalny gwarancje pierwszej poprawki muszą dotyczyć również wypowiedzi prowokacyjnych oraz niesympatycznej ekspresji, a sam fakt, że jakaś opinia może bulwersować lub oburzać, stanowi wręcz ,powód dla udzielenia jej ochrony konstytucyjnej”. Brennan odnotowywał także, iż teksańska regulacja - penalizująca wyłącznie te przypadki naruszenia fizycznej integralności sztandaru, które poważnie obrażają uczucia obserwatorów - nie respektuje zasady neutralności państwa, statuowanej w trzecim warunku standardu O'Briena. Konieczne jest tedy poddanie jej testowi strict scrutiny.

Ostatnią część swej analizy Brennan rozpoczął od rekapitulacji argumentów Teksasu, które miały dowodzić zgodności badanego unormowania 
z ustawą zasadniczą nawet w świetle najdalej idącego standardu surowego nadzoru sędziowskiego. W jego przekonaniu, istota przedstawionego przez pełnomocników stanu rozumowania opiera się na założeniu, że z uwagi na wyjatkową historyczną i symboliczną rolę flagi państwowej w amerykańskiej społeczności, władza publiczna dysponuje uprawnieniem do normatywnego oraz opatrzonego sankcją przymusu podtrzymywania tradycyjnego znaczenia sztandaru i do ochrony flagi jako symbolu narodowej jedności, który może być wykorzystywany jedynie w ograniczonych i prawnie uregulowanych kontekstach. Teksas przekonuje jednocześnie, że „kwestionowanie poglądu, zgodnie z którym narodowość i narodowa jedność są desygnatami flagi, bądź też podważanie istnienia narodowej jedności" są na tyle szkodliwymi treściami, że ich głoszenie może zostać zabronione. Wydaje się, że podsumowanie to rzetelnie odzwierciedla teksańską argumentację. Warto w tym miejscu zauważyć, że kolejne partie uzasadnienia, poświęcone refutacji tego ujęcia, stanowią mixtum compositum teorii prawnych oraz rozważań stricte doktrynalnych, co stawia pod poważnym znakiem zapytania zachowanie przez Brennana formalnie gloryfikowanej przezeń zasady neutralności państwa. Rozpocznijmy od prezentacji jurydycznych fragmentów brennanowskich wywodów. Chyba najsłynniejszy passus wyroku brzmiał: „Jeżeli istnieje jakiś kamień węgielny, stanowiący podwalinę pierwszej poprawki, to jest nim reguła, iż państwu nie wolno zakazywać wyrażania poglądów tylko $\mathrm{z}$ tego tytułu, że są one obraźliwe lub nieprzyjemne dla społeczności”. Sędzia przywoływał tutaj tym samym tradycyjny paradygmat liberalny w obszarze wolności ekspresji, który „pomniejsza znaczenie psychologicznych urazów jako podstawy dla działań rządu - obraza nie jest uzasadnieniem dla posługującej się przymusem" interwencji władzy w obręb jednostkowych praw ${ }^{55}$. Brennan dowodził, że żaden z precedensów ustanowionych przez Sąd Najwyższy nie zezwala organom państwa na promowanie ich własnego postrzegania roli flagi w społeczeństwie (jako jedynie słusznego wariantu) poprzez kryminalizację odnoszących się do niej określonych zachowań ekspresyjnych. Wydaje się, że w ocenie Brennana większość argumentów wysuwanych przez zwolenników penalizacji analizowanej wypowiedzi opiera się na włączeniu w obręb rozważań prawnych elementów dyskursu patriotycznego, gloryfikującego „wyjątkowy" status sztandaru państwowego w porównaniu z innymi symbolami ${ }^{56}$. Tymczasem, jak pisał dalej sędzia, „nie ma żadnego dowodu - ani w tekście Konstytucji, ani w naszych wyrokach interpretujaccych ją - że istnieje jakaś odrębna kategoria prawna przewidziana dla flagi jako takiej. Co więcej, nie zdziwiłoby nas wcale, gdyby okazało się, że osoby, które stworzyły naszą ustawę zasadniczą i napisały Pierwszą Poprawkę [...], nie darzyły przesadną rewerencją flagi

${ }^{55}$ T.C. Grey, What good is legal pragmatism?, w: Pragmatism in law and society, ed. by M. Brint and W. Weaver, Boulder 1991, s. 23.

${ }^{56}$ C.R. Ducat, Constitutional interpretation: rights of the individual, vol. II, Boston 2008, s. 876. 
brytyjskiej. Pierwsza Poprawka nie gwarantuje nam, że praktycznie święte dla całej naszej społeczności koncepty - jak choćby przekonanie, że dyskryminacja rasowa jest ohydna i destrukcyjna - nie będą mogły być kwestionowane na rynku idei". Brennan stwierdził także, że zasada wolności wypowiedzi obejmuje również prawo do ,wyboru formy, w jakiej autor przekazu pragnie wyrazić poglądy. Gdybyśmy przyjęli, że władza może zabronić palenia sztandaru, jeśli tylko wspomniany czyn prawdopodobnie może zagrozić symbolicznej roli flagi, ale może nań zezwolić, jeśli spalenie sztandaru promuje rzeczoną rolę - na przykład kiedy osoba ceremonialnie niszczy pobrudzoną flagę - to wówczas mówilibyśmy, że (w kontekście naruszania fizycznej integralności flagi) sztandar może służyć jako symbol - substytut dla pisanego lub mówionego słowa albo «skrót od umysłu do umysłu» - tylko w jeden sposób. Tym samym zezwolilibyśmy państwu na «dekretowanie, co jest ortodoksyjne» poprzez stwierdzanie, że wolno palić flagę w celu zakomunikowania swej postawy wobec jej samej lub jej desygnatów tylko wtedy, kiedy nie podważa się w ten sposób reprezentowania przez nią narodu i narodowej jedności. Dotąd nigdy nie konkludowaliśmy, iż rząd ma prawo zapewniać, że określony symbol będzie używany wyłącznie w celu wyrażania" oficjalnie aprobowanych tez. Pozostając jeszcze w obszarze argumentacji prawniczej i podnosząc kwestię związaną z formalną racjonalnością ustawodawcy, sędzia odwołał się także do popularnego argumentu $\mathrm{z}$ równi pochyłej ${ }^{57}$ : , Twierdzić, że rząd może pozwolić na stosowanie pewnych symboli tylko do przekazania zadekretowanych treści, to wkroczyć na terytorium pozbawione precyzyjnych i możliwych do obrony granic. Czy na podstawie takowej teorii władza mogłaby zakazać palenia flag stanowych? Kopii prezydenckiej pieczęci? Konstytucji? Jakim sposobem, oceniając takie hipotetyczne przypadki z perspektywy Pierwszej Poprawki, bylibyśmy zdolni określić, które z tych symboli są na tyle wyjątkowe, by zasługiwać na specjalny status? Aby rozstrzygnąć owe dylematy, musielibyśmy uciekać się do naszych politycznych preferencji, czego na gruncie Pierwszej Poprawki nie wolno nam czynić". Zamykając jurydyczną partię rozważań, Brennan stwierdził, że choć władza posiada legitymowany konstytucyjnie interes w zachowaniu flagi jako symbolu państwa $\mathrm{i}$ jego suwerenności (np. może wprowadzać przepisy determinujące poprawny sposób wywieszania sztandaru), to fakt ten bynajmniej nie daje rządzącym upoważnienia do obłożenia ekspresyjnej aktywności politycznej sankcją karną ${ }^{58}$.

Przytoczone wywody zdawały się dostatecznie eksplikować konkluzję orzeczenia. Jak już jednak zaznaczyliśmy, Brennan nie zrezygnował równocześnie z próby sformułowania szerszego doktrynalno-politycznego upra-

\footnotetext{
${ }^{57}$ Por. J.M. Coski, The Confederate Battle Flag: America's most embattled emblem, Cambridge 2005, s. 177.

Por. T.G. Pieper, Playing with fire: the proposed Flag Burning Amendment and the perennial attack on freedom of speech, „Saint John's Journal of Legal Commentary” vol. 11, s. 863-864.
} 
womocnienia wyroku (prawdopodobnie przewidując społeczne wzburzenie, jakie wywoła jego rozstrzygnięcie). Po pierwsze, zaangażował się w debatę (z perspektywy maksymalistycznie zorientowanej polityki prawa) na temat celowości teksańskiej regulacji. W jego opinii tolerowanie ekspresyjnego bezczeszczenia sztandaru w najmniejszej mierze nie pomniejsza jego symbolicznej roli w amerykańskim społeczeństwie, nie podważa wartości reprezentowanych przez flagę oraz nie uszczupla inspirowanych przez nią uczuć patriotycznych. Gesty nieznanych powszechnie osobników w rodzaju Johnsona nie są po prostu zdolne spowodować takich konsekwencji. Co więcej, argument o obraźliwości analizowanej ekspresji symbolicznej podnoszony przez pełnomocników Teksasu sam w sobie dostarcza potwierdzenia, że „,szczególna rola flagi nie jest w niebezpieczeństwie; gdyby była, to nikt nie wszczynałby zamieszek i nie obrażał się z powodu jej podpalenia". Po drugie, Brennan przedstawił osobistą interpretację doktrynalnego znaczenia sztandaru. Jego zdaniem, zasłużone wyjątkowe miejsce flagi w amerykańskich sercach „będzie wzmocnione, a nie osłabione naszym dzisiejszym orzeczeniem. Wyrok jest bowiem reafirmacją zasad wolności i inkluzywności, które sztandar najlepiej odzwierciedla". Zgodnie $\mathrm{z}$ przedstawionym ujęciem, flaga reprezentuje przede wszystkim przywiązanie Amerykanów do pryncypiów swobody wypowiedzi statuowanych w Pierwszej Poprawce ${ }^{59}$, a okazywanie tolerancji dla krytycyzmu wyrażonego przez Johnsona stanowi „znak i źródło" amerykańskiej siły. Za trafny należy uznać pogląd, zgodnie z którym Brennan nie ujawnia w orzeczeniu swej niewrażliwości na narodowe symbole (ale raczej postrzega jak najszerzej rozumianą klauzulę wolności słowa jako właśnie taki symbol), a w jego uzasadnieniu przywiązanie do abstrakcji i racjonalnego dyskursu uzyskuje prymat nad romantyczna, „bardziej skonkretyzowaną i mniej centralną" dla amerykańskiego doświadczenia romantyczną ikonografią ${ }^{60}$. Jak przekonywał ostatecznie Brennan, wyrok to świadectwo hołdu dla narodowej elastyczności ${ }^{61}$, a karanie desakralizacji flagi wcale nie oznacza jej czczenia, albowiem postępowanie takie rozwadnia fundamentalne wartości, które sztandar reprezentuje. Po trzecie, ważnym elementem uzasadnienia jest odmowa rezygnacji $\mathrm{z}$ argumentacji nawiązującej do patriotyzmu i ustapienia $\mathrm{w}$ tym zakresie pola zwolennikom penalizacji. Brennan odwołał się tutaj do liberalnej wizji społeczeństwa, która ufundowana jest na aksjologicznych podwalinach, zakorzenionych - w przekonaniu sędziego - w tożsamości obywateli amerykańskich. W jego przeświadczeniu narodowy ideał zakłada zwalczanie

${ }^{59}$ R. Spangenburg, K. Moser, Civil liberties, Tarrytown 2006, s. 86.

${ }^{60}$ F.H. Buckley, Liberal nationalism, „UCLA Law Review” vol. 48, s. 258-259.

${ }^{61}$ Nawet przychylnie nastawiony do Brennanowskiego uzasadnienia Christopher L. Eisgruber uznał te konkluzje za przesadzone, gdyż traktowanie palenia flagi jako niemalże okazji do patriotycznej celebracji jest przejawem nadmiernego racjonalizmu, bagatelizującego uzasadnione emocje społeczne wywoływane przez sztandar, w: Ch.L. Eisgruber, Is the Supreme Court an educative institution?, „New York University Law Review” vol. 67, s. 984-985. 
zagrożeń płynących z wolnego słowa ,nie poprzez karanie tych, którzy myślą inaczej, ale poprzez przekonanie ich, że się mylą" (z wyjątkiem sytuacji, w której pojawia się jasne i bezpośrednie zagrożenie dla fundamentalnego interesu publicznego). Właściwa reakcją na fałsze i kłamstwa jest dyskusja i edukacja (czyli ,więcej słów”), a nie wymuszanie milczenia. Jak puentował sędzia, „właściwą odpowiedzią na palenie flagi jest wymachiwanie własną; nie istnieje celniejsza riposta wobec przekazu podpalacza sztandaru aniżeli salutowanie płonącej fladze; nie ma lepszego sposobu na podtrzymanie godności choćby i podpalonej flagi aniżeli [...] pełne szacunku pogrzebanie jej pozostałości". Ze stricte psychologicznego punktu widzenia użycie przez Brennana omówionej w tym akapicie retoryki jest bardzo łatwe do wyjaśnienia brakiem jego aprobaty dla monopolizowania dyskursu patriotycznego przez środowiska konserwatywne. Osobiście sądzę jednak, że ostatnie partie wyroku - jak konstatuje między innymi David E. Marrion ${ }^{62}$ - zawierają konstytucyjnie nieoczywistą oraz prawnie i aksjologicznie kontrowersyjną wizję społeczeństwa składającego się z jednostek posiadających maksymalny zakres praw do indywidualnego samookreślenia czy autoekspresji, będących zarazem afirmacją ich człowieczeństwa, emanacją ludzkiej godności oraz elementem sprawowania przez człowieka kontroli nad własnym życiem. W moim przekonaniu, powstrzymanie się przez sędziego od moralistycznej i subiektywnej narracji w niczym nie uchybiłoby doktrynalnej spójności orzeczenia trafnie akcentującego rolę wolności słowa, chroniąc je zarazem - przynajmniej częściowo - przed zarzutem aktywizmu.

Enuncjacje Brennana spotkały się z bardzo ostrą krytyką ze strony czterech członków Sąu Najwyższego. Główne votum separatum wobec wyroku sporządził prezes Sądu Najwyższego William H. Rehnquist. Fakt ten trudno per se uznać za zaskakujący. Sprzeciw Rehnquista wobec supozycji Brennana może być łatwo wyjaśniony podstawowym składnikiem przyjmowanego przezeń paradygmatu orzeczniczego, którym jest daleko posunięta deferencja sądownictwa względem legislatywy, legitymizowana radykalnie pojmowaną zasadą wstrzemięźliwości judykatury i skutkująca niechęcią do traktowania (w nieoczywistych sytuacjach) uchwalonych demokratycznie regulacji jako sprzecznych z ustawą zasadniczą ${ }^{63}$. Niespodziewana jest zaś treść omawianego zdania odrębnego. Otóż wywody Rehnquista przepojone są emocjami oraz afektowaną retoryką. W obronie swojego stanowiska sędzia nie zawahał się nawet przywołać poematów autorstwa Ralpha Waldo Emersona oraz Johna Greenleafa Whittiera. Co więcej, część użytych przez prezesa Sądu Najwyższego argumentów ewidentnie nie ma wiele wspólnego z kwestią

${ }^{62}$ D.E. Marrion, The jurisprudence of Justice William J. Brennan, Jr: the law and politics of "libertarian dignity", Lanham 1997, s. 83-86, 88.

${ }^{63}$ Por. np. B.A. Perry, A.J. Mikva, The priestly tribe: the Supreme Court s image in the American mind, Westport 1999, s. 59-60. 
konstytucyjności teksańskiej regulacji. Rehnquist powoływał się na przykład na liczne wypowiedzi polityków, odczucia znacznego segmentu opinii publicznej, powszechność występowania w federalnym i stanowym prawodawstwie amerykańskim norm penalizujących desakralizację flagi, obecność sztandaru na znaczkach pocztowych lub też ofiarność żołnierzy armii Stanów Zjednoczonych. Jak zgryźliwie komentuje Phillip J. Cooper, z uzasadnienia Rehnquista wynika niemal, że to właśnie Sąd Najwyższy jest odpowiedzialny za śmierć amerykańskich żołnierzy piechoty morskiej z rąk japońskich (a już z pewnościa, że lekceważy ich patriotyzm oraz poświęcenie dla dobra kraju ${ }^{64}$. W tym kontekście słuszna wydaje się opinia Stephena M. Feldmana, że wskazany fragment votum separatum to oryginalny przykład zastosowania w orzecznictwie konserwatywnego wariantu metodologii oraz doktryny postmodernistycznej ${ }^{65}$.

Z prawnego punktu widzenia punktem wyjścia refleksji Rehnquista było uznanie sztandaru państwa za wyjątkowy obiekt, którego szczególny status umożliwia władzom publicznym sięganie po szeroką paletę środków gwarantujących ochronę fizycznej integralności i symbolicznej roli flagi. Odwołując się do amerykańskich tradycji, sędzia pisal, że ,przez ponad 200 lat sztandar Stanów Zjednoczonych zajmował wyjątkową pozycję jako symbol naszego narodu, a wyjątkowość ta uzasadniała rządowy zakaz podpalania flagi w sposób, w jaki uczynił to podsądny Johnson [...] Amerykański sztandar [...] jest dziś widomym symbolem ucieleśniającym nasz naród. Nie reprezentuje on poglądów żadnego ze stronnictw politycznych, ani też żadnej konkretnej filozofii politycznej. Flaga nie jest po prostu kolejną «ideą» albo «punktem widzenia», który musi konkurować o uznanie na wolnym rynku idei. Miliony Amerykanów traktują ją $z$ niemalże mistyczną rewerencją która jest całkowicie niezależna od posiadanych przez nich poglądów społecznych, politycznych i filozoficznych”. Poszukując dowodów potwierdzających tę szczególną pozycję i umocowanie flagi, Rehnquist nie był jednak w stanie sformułować kompleksowej i koherentnej teorii pozwalającej wykluczyć bezczeszczenie sztandaru spod ochrony pierwszej poprawki. Należy wręcz stwierdzić, że sędzia był gotów zaaprobować całkowicie dowolną racjonalizację tezy o zgodności skazania Johnsona $\mathrm{z}$ konstytucją. W różnych fragmentach swojego wywodu Rehnquist zdawał się bowiem już to negować lingwistyczny oraz ekspresyjny charakter palenia flagi (porównując to zachowanie do wydania „,nieartykułowanego chrząknięcia”), już to definiować rzeczone postępowanie jako wypowiedź pozostająca poza sferą zainteresowania pierwszej poprawki (tj. niestanowiącą esencjonalnej części procesu prezentacji poglądów oraz posiadającą na tyle nikłą wartość z perspektywy odkrywania prawdy, że jakie-

${ }^{64}$ P.J. Cooper, Battles on the Bench: conflict inside the Supreme Court, Lawrence 1995, s. 60.

${ }^{65}$ S.M. Feldman, American legal thought from premodernism to postmodernism: an intellectual voyage, New York 2000, s. 183. 
kolwiek pożytki społeczne z niej płynące są w oczywisty sposób podrzędne względem społecznego interesu polegającego na zapobieganiu prawdopodobnemu naruszaniu porządku publicznego), już to traktować profanowanie flagi jako komunikowanie określonych poglądów w sposób, który można w zgodzie z konstytucją zdelegalizować (na podstawie standardów pozwalających na regulowanie sposobu transmisji określonych idei czy choćby na podstawie prawa własności intelektualnej). Summa summarum, żaden ze wskazanych tutaj argumentów nie został jednak przez Rehnquista precyzyjnie rozwinięty, co pozwala uznać jego wywód przede wszystkim za emanację ideowych preferencji, a nie za próbę sformułowania przekonującej teorii prawnej66.

Oprócz - a właściwie $\mathrm{z}$ powodu - niemałego oburzenia społecznego spowodowanego orzeczeniem, wyrok wywołał również szereg konsekwencji natury politycznej. W pierwszej kolejności Kongres Stanów Zjednoczonych podjął próbę nowelizacji ustawy zasadniczej, polegającej na wprowadzeniu do jej treści poprawki stanowiącej, że ustawodawca federalny oraz legislatywy stanowe są uprawnione do ,zakazania fizycznej desakralizacji flagi Stanów Zjednoczonych". Projekt nie zdobył wymaganej kwalifikowanej większości w parlamencie ${ }^{67}$. Po upadku projektu nowelizacji konstytucji Kongres zdecydowal o wprowadzeniu poprawki do federalnej ustawy o ochronie flagi z 1968 r., która czyniła przestępstwem zagrożonym karą grzywny lub pozbawienia wolności w wysokości do roku działanie polegające na świadomym „uszkodzeniu, oszpeceniu, fizycznym splugawieniu, podpaleniu, trzymaniu na ziemi lub podłodze albo zdeptaniu" flagi amerykańskiej. Poprawka przewidziała wyjątek dla zachowań zmierzających do zniszczenia zużytych i pobrudzonych sztandarów i ustanawiała specjalną przyspieszoną procedurę dotyczącą rozpatrywania powstałych na jej tle sporów sądowych. Niewatpliwie intencją Kongresu była eliminacja wady prawa teksańskiego - penalizujacego jedynie takie przypadki niewłaściwego traktowania flagi, które poważnie obrażają uczucia innych osób - wykluczającej (przynajmniej w mniemaniu SN) możliwość zakwalifikowania go jako unormowania niedyskryminującego treściowo ${ }^{68}$. Zabieg ten również skończył się jednak niepowodzeniem wskutek decyzji Sądu Najwyższe-

${ }^{66}$ Por. J.B. Raskin, Overruling democracy: The Supreme Court vs. The American People, New York and London 2003, s. 211-212.

${ }^{67}$ J.R. Vile, Encyclopedia of constitutional Amendments, proposed Amendments, and amending issues, Santa Barbara-Denver-Oxford 2003, s. 137-138. Poprawka nie była zresztą wzorem doskonałości w zakresie techniki legislacyjnej. Por. W. van Alstyne, Freedom of speech and The Flag Anti-Desecration Amendment: antinomies of constitutional choice, „Free Speech Yearbook” vol. 29, s. 97-102; J. B. Raskin, Overruling, s. 219.

${ }^{68}$ D.P. Kommers, J.E. Finn, G.J. Jacobsohn, American constitutional law: essays, cases and comparative notes, Lanham 2004, s. 746. Przypomnijmy, że konceptualizacja przepisów penalizujących nieodpowiednie traktowanie sztandaru państwowego jako neutralnych treściowo (a, mówiąc precyzyjniej, realizujących interesy niezwiązane $z$ tłumieniem wolności słowa) pozwoliłaby na uznanie ich za unormowania nakładające jedynie akcydentalne brzemiona na sferę ekspresji oraz na ocenianie ich konstytucyjności poprzez pryzmat lagodnego testu O'Briena. 
go w sprawie Stany Zjednoczone vs. Eichman ${ }^{69}$. Wyrok ten zapadł identyczną większością głosów, co rozstrzygnięcie w sprawie Texas vs. Johnson; przy niezmienionym składzie personalnym, żaden z sędziów nie zmienił swojego zdania $\mathrm{w}$ kwestii konstytucyjności kryminalizowania profanacji flagi. Ponownie sporządzający uzasadnienie Brennan jasno i klarownie skonstatował, że wszelkie normatywne próby ochrony sztandaru państwowego jako „unikatowego i nieskażonego symbolu narodowego" przed antypatycznym, ale ekspresyjnym atakiem stanowią pogwałcenie pierwszej poprawki.

Na zakończenie chciałbym przedstawić osobistą ocenę przedmiotowego rozstrzygnięcia Sądu Najwyższego. Moim zdaniem, konsekwentne zastosowanie wypracowanych przez Sąd Najwyższy dyrektyw interpretacyjnych dotyczących klauzuli wolności słowa nieuchronnie prowadzi do objęcia ekspresyjnej profanacji flagi protekcją pierwszej poprawki ${ }^{70}$. Amerykańska doktryna konstytucyjnoprawna w zakresie wolności słowa jasno statuuje, że psychiczny dobrostan czy komfort jednostek (których uczucia zostają urażone - częstokroć w sposób bardzo poważny - zbezczeszczeniem sztandaru) co do zasady nie stanowią dostatecznej przesłanki legitymującej ograniczenie swobody wypowiedzi. Wyrok w sprawie Texas vs. Johnson jest zatem osadzony na trwałych fundamentach doktrynalnoprawnych ${ }^{71}$, potwierdza gotowość Sądu Najwyższego do udzielania konstytucyjnej ochrony choćby „najbardziej prowokacyjnej ekspresji" ${ }^{72}$, utwierdza wymóg zachowania przez państwo neutralności światopoglądowej i treściowej względem wypowiedzi symbolicznych ${ }^{73}$ oraz stanowi przejaw przekraczającego polityczne podziały przywiązania amerykańskiego sądownictwa do szerokiego (niemalże libertariańskiego) pojmowania gwarancji pierwszej poprawki oraz woli podejmowania aktywnych działań w jej obronie ${ }^{74}$. Wyrok pokazał, że, zgodnie $z$ orzecznictwem Sądu Najwyższego, pierwsza poprawka wyklucza skuteczne powoływanie się na abstrakcyjne interesy publiczne w celu usprawiedliwienia wprowadzenia ograniczeń ekspresyjnej aktywności ${ }^{75}$. Niewątpliwie z ujęciem takim można

${ }^{69} 496$ U.S. Reports 310 (1990).

${ }^{70}$ Ponieważ, co do zasady, uznaje generalną interpretację pierwszej poprawki, proponowaną konsekwentnie przez Sąd Najwyższy przez ostatnie kilkadziesiąt lat, za trafna, per necessitas uważam również analizowany w artykule wyrok za właściwy.

${ }^{71}$ S.E. Rush, Feminist judging: an introductory essay, w: Feminist jurisprudence, women and the law: critical essays, research agenda, and bibliography, ed. by B. Taylor, S.E. Rush and R.J. Munro, Buffalo 1999, s. 605.

72 D.A. Downs, Eichman, United States, w: The Oxford guide to United States Supreme Court decisions, ed. by K.L. Hall, New York 2001, s. 83.

${ }_{73}$ O.M. Fiss, Silence on the street corner, w: Public values in constitutional law, ed. by S.E. Gottlieb, Ann Arbor 1993, s. 209-210.

${ }^{74}$ F.P. Lewis, The context of judicial activism: the endurance of the Warren Court legacy in a conservative age, Lanham 1999, s. 37-38.

${ }_{75}$ P. Hoffman, K. Martin, United States, w: Secrecy and liberty: national security, freedom of expression and access to information, ed. by S. Coliver, P. Hoffman, J. Fitzpatrick and S. Bowen, The Hague 1999, s. 485. 
polemizować i optować za przyjęciem bardziej konserwatywnego czy komunitariańskiego punktu widzenia. Niemniej jednak wyrok w sprawie Texas vs. Johnson bezproblemowo wkomponowuje się w amerykańską tradycję jurydyczną w obszarze pierwszej poprawki. Już chociażby tylko z tego powodu (pomijając merytoryczną zawartość rozstrzygnięcia) uważam pojawiająca się często $\mathrm{w}$ debacie publicznej fundamentalną i bardzo radykalną krytykę orzeczenia Sądu Najwyższego za drastycznie przesadzoną. Przykładem tak niepotrzebnie wyostrzonej retoryki (obecnej również w słowach cytowanych już Borka czy Marriona) jest na przykład diagnoza Mortona Kaplana, w którego ocenie wyrok podważa społeczny szacunek wobec zasady wolności słowa, fetyszyzuje indywidualne swobody, jest ekspresyjny i wręcz dysfunkcjonalny z perspektywy podstawowych interesów narodowych ${ }^{76}$. Sądzę, że tak daleko posunięte oskarżenia nie mają wartości merytorycznej, ale stanowią raczej próbę delegitymizacji moralnej oponenta. Obiektywizm nakazuje jednak w tym momencie dostrzec, że także dyskurs antypenalizacyjny bywa przesiąknięty demagogią i uproszczeniami. Przykładowo William W. van Alstyne nie waha się zestawić poglądu osób akceptujących kryminalizację profanowania flagi z mentalnością chińskich przywódców, siłowo thumiących protest obywatelski na Placu Niebiańskiego Spokoju. Jego zdaniem, wprowadzanie prawnej ochrony narodowych symboli to próba dekretowania sztucznej narodowej jedności (nieistniejącej spontanicznie w ludzkich sercach i umysłach), właściwa dla państw totalitarnych, sakralizujących określone emblematy czy idee oraz wyjmujących je spod krytyki ${ }^{77}$. Lauren B.E. Freeman przekonuje natomiast, że zwolennicy penalizacji usiłują przenieść debatę o dyskursywnej przyzwoitości z płaszczyzny wolności słowa na płaszczyznę ikonograficzna żądającą od jednostek ,lojalnej autocenzury i osobistej dyscypliny”. Roszczenie takie jest przejawem Americana Nervosa, specyficznego schorzenia społecznego polegającego na kompulsywnym dławieniu się narodowym rytuałem i symboliką ${ }^{78}$. Dla osoby dość dobrze pamiętającej polską rzeczywistość lat 80 . powyższe supozycje wydają się mocno oderwane od realiów. W moim przekonaniu, traktowanie rezygnacji z prawnej ochrony narodowej symboliki jako miarodajnego probierza statusu zasady wolności ekspresji w danym modelu ustrojowym, jako swoistego metra z Sevres w odniesieniu do kwestii przestrzegania w nim praw obywatelskich, jest daleko idąca przesada. Owszem, Sądu Najwyższego miał słuszność obejmując czyn Johnsona gwarancjami pierwszej poprawki. Jednak hipotetyczne popełnienie przezeń błędu w ocenie na przykład podpalenia flagi nie rzutowałoby znacząco na obowiązujący w USA zakres indywidualnej swobody wypowiedzi.

${ }^{76}$ M.A. Kaplan, Law in a democratic society, St. Paul 1993, s. 144-147.

${ }^{77}$ W.W. van Alstyne, Freedom of speech, s. 102-103.

${ }^{78}$ L.B.E. Freeman, Queer nationality, w: National identities and post-Americanist narratives, ed. by D.E. Pease, Durham 1994, s. 151. 
Oceniając spór odnośnie do konstytucyjności antydesakralizacyjnych unormowań z perspektywy ponad dwóch dekad dostrzegalny po obydwu stronach barykady poziom emocji wydaje się wręcz trudny do pojęcia. Mutatis mutandis, przypomina to nieco polskie dyskusje u progu lat 90 . XX w. dotyczące legalizacji „miękkiej pornografii”. Tak drastyczny spadek zainteresowania opinii publicznej określoną problematyką zazwyczaj świadczy pejoratywnie o jakości dyskursu. Pozwólmy sobie jednak na optymistyczne zakończenie tego artykułu, przywołując pogląd George'a P. Fletchera. Jak argumentuje konstytucjonalista, wyrokowi Sądu Najwyższego USA w sprawach Texas vs. Johnson można postawić wiele racjonalnych zarzutów (błędnie konceptualizuje profanację flagi jako „słowo" w rozumieniu pierwszej poprawki, nie rozróżnia treści oraz formy przekazu, bezpodstawnie odmawia emocjonalnemu przywiązaniu obywateli do sztandarowego oraz newralgicznego narodowego emblematu - odmiennie niż takim interesom, jak prawa autorskie, własność prywatna i osobista reputacja - statusu wartości przebijającej zasadę wolności słowa i upoważniającej władzę publiczną do wyciszania określonych komunikatów). Niezależnie od takich ocen trzeba jednakże przyznać, że orzeczenie to trwale zakorzeniło się w konstytucyjnej tożsamości Amerykanów. Rozstrzygnięcie eksponuje bowiem fakt, że wypowiedzi stanowią medium, poprzez które obywatele Stanów Zjednoczonych najpełniej wyrażają swą autonomię i emancypację spod kurateli państwa. Tym samym kontrowersyjna decyzja Sądu Najwyższego powinna być traktowana jako swoiste ucieleśnienie specyficznego amerykańskiego ducha $\mathrm{z}$,,irrewerencją nieprzerwanej amerykańskiej rewolucji”. Ostatecznie zatem - w przekonaniu Fletchera - wyrok potwierdził, że obrona wolności słowa to „część bycia Amerykaninem”: poszanowanie osobistych ekspresyjnych swobód jednostki jest konstytutywnym elementem tamtejszej kultury ${ }^{79}$. Rezultat ten można chyba w ostatecznej instancji uznać za pozytywny.

${ }^{79}$ G.P. Fletcher, Constitutional identity, w: Constitutionalism, identity, difference, and legitimacy: theoretical perspectives, ed. by M. Rosenfeld, Durham 1994, s. 226-232. 